\title{
Patterns of Nestedness in Carnivorous Mammals in the Arauca- Nía Coastal Mountains of Southern Chile
}

\author{
Rocío Sanhueza, Wladimir Moya \& Jaime R. Rau*
}

Laboratorio de Ecología, Departamento de Ciencias Biológicas \& Biodiversidad, Universidad de Los Lagos, Campus Osorno. P.O. Box 933, Osorno, Chile

${ }^{*}$ Corresponding author, e-mail: jrau@ulagos.cl

\begin{abstract}
The probability of existence or not of local extinctions of six species of carnivorous mammals was analyzed by ordering the species composition in nested subsets in 7 fragments of forest habitats in the Coastal Mountains in the Araucanía Region, in southern Chile. Nested Temperature Calculator (NTC) and BINMATNEST computer programs were used to process the results. The first software provided a temperature in the archipelago of 28.21 degree Celsius, whereas the second program showed a nesting temperature of 16.58 degree Celsius. The computer software used in this study suggest that there is no nesting pattern at the level species composition of carnivorous mammal assemblage in the evaluated area, which may be due to the habitat use characteristics of the different carnivorous mammals studied here.
\end{abstract}

Keywords: Araucanía Region; species composition; habitat fragmentation; carnivorous mammals; nested subsets.

\section{1.-. Introduction}

Habitat fragmentation has been one of the main causes of biodiversity loss worldwide (Crooks 2002; Lindenmayer \& Fisher 2006; Echeverría et al., 2012; Otavo 2017). Among the main effects of fragmentation at the landscape level, reduction of size and quality of forest habitats, increase of edge and number of patches and loss of connectivity can be mentioned (Lindenmayer \& Fisher 2006; Zúñiga et al., 2009; García 2011).

In Chile, anthropic processes such as the substitution of native forest by plantations of exotic species, agricultural crops and forest fires among others have been associated with the degradation and loss of natural forests (Acosta 2001; Echeverría et al., 2006). The process of habitat fragmentation has been intense, particularly in the central depression of southern and central Chile, rather than in the surrounding mountain ranges. In such depression, the original native forest has practically disappeared and in southern Chile, it has remained fragmented and inserted into a matrix of agro-ecosystems.

In the Araucanía Region, the progress of the fragmentation process is evident and it has been oriented to the qualification of lands for agriculture and livestock. Likewise, in the last 30 years, the native forest has been substituted by plantations of exotic species (Pinus radiata and Eucalyptus spp.). Thus, the native forest has been reduced to scattered fragments, inserted into a silvoagricultural matrix, with few remnants of large size, mainly located in the area of the Andes Mountains.

The effects of habitat fragmentation on biodiversity can be very variable, including changes in abundance and distribution of species, which respond not only to the characteristics of the fragments (size, shape and spatial arrangement), but also to the characteristics of the affected species. In the case of carnivores, in general they are considered very vulnerable to local extinction, as a result of habitat fragmentation, low population numbers and territorial requirements (Noss et al., 1996). However, not all are equally sensitive and such sensitivity would be mainly due to characteristics such as body size, size of their home range or niche breadth (specialists or habitat generalists (Crooks 2002, Swihart et al., 2003, Zúñiga et al., 2009). 
At regional scale, few studies have analyzed the effects of fragmentation of native forest on fauna. Given its ecological role, it is important to know to what extent fragmentation changes the patterns of species composition of carnivorous mammal assemblages. The theory of nested subsets is presented as one of the tools for obtaining nested subsets patterns. According to this theory, given a set of replicas of a same habitat that vary in its composition, such as species in islands of an archipelago, less diverse habitats tend to be subsets of habitats that assemble a greater number of species (Santos \& Tellería 2006). In a group of perfectly nested habitats, which is unusual, there is always a certain amount of noise, in which a taxon is present in a habitat or smaller size island it is also, necessarily, in the larger ones (Wright et al., 1998). On the contrary, if a taxon is absent from a certain set, it will also be absent in the least extensive and, in turn, less diverse. It is expected that fragments of smaller area will contain an impoverished set of species, respect to those of larger area (Rau et al., 2015).

With this background, this work evaluates whether the species composition of carnivorous mammals of 7 fragments of forest habitat in the southern area of the Coastal Mountains of the Araucanía Region responds or not to a distribution pattern of nested subsets, in order to determine the probability of occurrence of local extinctions. This was evaluated using the "system temperature" as measure, in analyzes carried out in computer programs NTC and BINMATNEST.

\section{Materials and methods}

\subsection{Study area}

The study area corresponds to the southern area of the Coastal Mountains of the Araucanía Region, southern Chile (Figure 1), from the southern side of the Toltén River until the border with Los Ríos Region, covering a total area of 209,430 ha. Such area is characterized by a vegetation of the Valdivian laurel-leaved forest (Gajardo, 1993). This has been modified historically by anthropic action, being presented today mostly in the form of relicts of mixed vegetation and sprout forests. These formations belong mainly to southern beech (Nothofagus obliqua)- Chilean laurel (Laurelia sempervirens)- litchi tree (Persea lingue) and temu (Blepharocalyx cruckhansksii)-pitra (Myrceugenia exsucca) in hills and low areas, respectively (see Hauenstein et al., 2002).

\subsection{Sampling sites}

Within the study area and based on land use and soil coverage performed on the basis of a Landsat ETM+ 2003 satellite image a set of 20 fragments of native forest, with a surface area greater than 1 ha, was randomly selected. Each selected fragment was visited to verify its status (category of land use and intervention status) and the feasibility of performing the field work. With this verification, the sample was reduced to 7 fragments one sampled (exception Boroa 1 fragment that was sampled twice in July 2006 and January 2007 and Nueva Etruria fragment that was also sampled twice in September 2006 and March 2007), with surfaces from 3.1 ha to 239.1 ha, located in the communes of Pitrufquén, Toltén, Gorbea and Loncoche (Table 1; Figure 1).

Table 1 Characterization of the 7 sampling sites within a fragmented forest landscape in the Coastal Mountains of the Araucanía Region, southern Chile.

\begin{tabular}{|c|c|c|c|c|c|c|c|}
\hline $\begin{array}{r}\text { ID Frag- } \\
\text { ment }\end{array}$ & Site & Sector & Commune & $\begin{array}{r}\text { Coord. Ref } \\
\text { (UTM) }\end{array}$ & $\begin{array}{l}\text { Area } \\
\text { (ha) }\end{array}$ & $\begin{array}{c}\text { Category of } \\
\text { use }\end{array}$ & Matrix \\
\hline 1 & $\begin{array}{c}\text { Boroa } \\
\text { Norte } \\
1\end{array}$ & Boroa Norte & Toltén & $665984 \mathrm{~N} / 5652334 \mathrm{E}$ & 14.0 & BNA & $\mathrm{AF}$ \\
\hline 2 & Licancullín & Colonia San Jorge & Toltén & $678416 \mathrm{~N} / 5654733 \mathrm{E}$ & 46.8 & RN & $\mathrm{AF}$ \\
\hline 3 & El Socorro & Colonia San Jorge & Toltén & $672161 N / 5654558 \mathrm{E}$ & 2,309.1 & BNA & $\mathrm{F}$ \\
\hline 4 & Afquintué & Afquintué & Loncoche & $707838 \mathrm{~N} / 5644950 \mathrm{E}$ & 6.8 & BNA & $\mathrm{AF}$ \\
\hline
\end{tabular}




\begin{tabular}{|c|c|c|c|c|c|c|c|}
\hline 5 & $\begin{array}{c}\text { Nueva } \\
\text { Etru- } \\
\text { ria }\end{array}$ & $\begin{array}{c}\text { Comuy y Nueva Etru- } \\
\text { ria/Mantahue }\end{array}$ & $\begin{array}{l}\text { Pitruf- } \\
\text { quén/Gor- } \\
\text { bea }\end{array}$ & $685227 \mathrm{~N} / 5665714 \mathrm{E}$ & 146.5 & RN & $\mathrm{F}$ \\
\hline 6 & $\begin{array}{c}\text { Boroa } \\
\text { Norte } \\
2\end{array}$ & Boroa Norte & Toltén & $667521 N / 5652049 \mathrm{E}$ & 23.1 & $\mathrm{BM}$ & $\mathrm{AF}$ \\
\hline 7 & $\begin{array}{c}\text { Boroa } \\
\text { Norte } \\
3\end{array}$ & Boroa Norte & Toltén & $663638 \mathrm{~N} / 5653327 \mathrm{E}$ & 3.1 & BNA & $\mathrm{AF}$ \\
\hline
\end{tabular}

BNA: Adult native forest RN: Native sprout forest BM: Native forest AF: Agroforestry F: Forestry

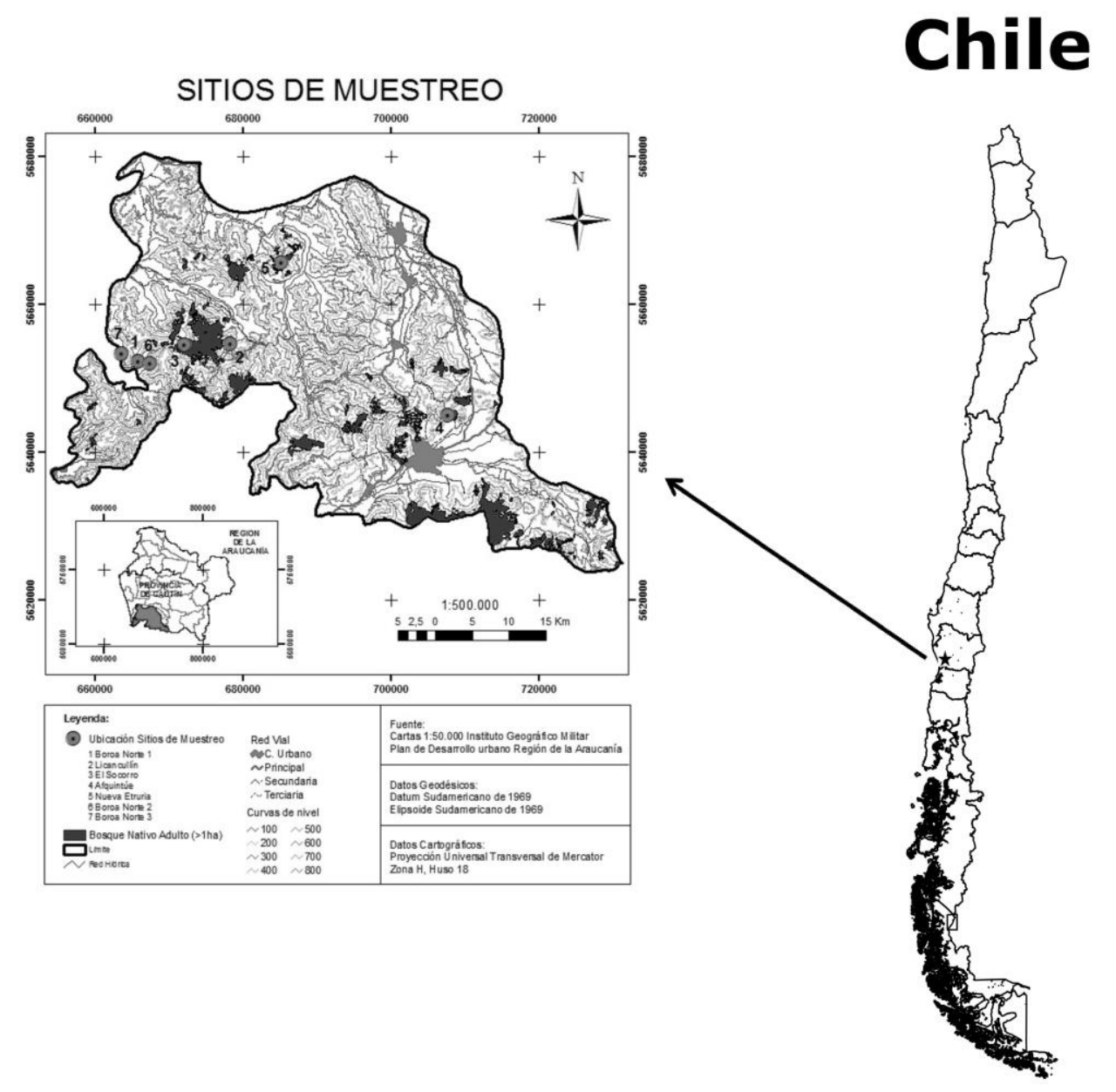

Figure 1 Map of location of the 7 sampling sites, Coastal Mountains, Araucanía Region, southern Chile.

\subsection{Sampling techniques of carnivorous mammals}

In each of the 7 fragments, the present species of carnivorous mammals were identified through the use of indirect detection techniques such as scent-stations and active search of signs (e.g., feces and tracks) in roads and paths. Scent-stations were arranged every $200 \mathrm{~m}$ approximately, in roads close to native forest. Urine of American wild cat (Lynx rufus) was used to attract the presence of the carnivores. The scent-stations remained active during two consecutive nights. The active search for tracks and feces in roads and paths was carried out during the entire working time in the fragment. Besides our field 
work experience, Acosta \& Simonetti's guide (1999) was used to identify the tracks recorded. It is known that scent-stations are more effective than camera-traps to record the species richness and composition of Mediterranean terrestrial mammal assemblages (Suárez-Tangil \& Rodríguez 2021).

\subsection{Information analysis}

The study of the composition of species has a focus centered on the features of life history and interactions between them (i.e., a biological approach), being possible to identify which ones are more sensitive to the process of habitat fragmentation. With this background, the study privileged the composition of species to better explain the possible nesting patterns, since the isolated study of richness of species has a rather statistical/mathematical approach (Rau, 2020).

In order to identify the existence of nesting in the composition of carnivorous mammal species, the computer program NTC (Atman \& Patterson, 1995) was used. This program requires the construction of a binary data matrix in a txt format, in which " 0 " represents the absence, and " 1 " corresponds to the presence of the species, leaving the first line blank. The matrix consisted of 6 columns ( 6 species) and 7 rows ( 7 fragments). The utility of the program allows calculating: (i) the percentage of occupation of the matrix: (ii) its maximum packaging, that is, the reordering of rows and columns of the original matrix, minimizing absences and unexpected presences; (iii) idiosyncratic temperatures, i.e., peaks of temperatures respect to a fragment or species that are higher than the temperature of the entire matrix; and (iv) the probabilities of the distribution and occupation patterns of the matrix (the latter was not considered in this work).

The NTC software has been criticized by several authors (Fisher \& Lindenmayer, 2002; Ulrich \& Gotelli, 2007a, b, Ulrich et al., 2009), due to the way in which the temperature is calculated, the way in which the matrix is organized to pack it to the maximum, the way in which the levels of probability are calculated, and the suitability of temperature as an adequate measurement of the nesting of the matrix. Therefore, for comparative purposes, this study also used the BINMATNEST computer program (Rodríguez-Gironés \& Santamaría, 2006). BINMATNEST uses three null mathematical models: model 1 by Atmar \& Patterson (1995), model 2 by Fisher \& Lindenmayer (2002) and model 3, proposed by Rodríguez-Gironés \& Santamaría (2006). In the latter, the authors point out that this is a model with greater statistical "robustness" since it randomizes the order of the fragments, minimizing statistical errors and taking into account the passive sampling.

Higher temperatures suggest a lower degree of nesting and therefore, a lower probability of local extinctions. On the other hand, lower temperatures (ca. 0 degree Celsius) indicate a higher degree of nesting with greater probability of local extinctions.

In order to observe the effect of the area of fragments on species richness, four different simple regression analyses (linear, potential, logarithmic and exponential) were performed by using the VassarStats statistical software, available on the website $<\mathrm{http} / / / \mathrm{www}$.VassarStats.net $>$, to determine the statistical significance from the determination coefficients of the relation between the number of species and the area of 7 fragments. The number of species was averaged when the same fragment (Boroa Norte 1 and Nueva Etruria) was sampled at different times (see above). Log base 10 was used to express the area in square kilometers.

\section{Results}

The species richness and composition of the carnivore mammal assemblage was not affected by forest fragmentation. In Table 2 are presented the presence and absences of 6 species of carnivorous mammals in seven fragments of the Coastal Mountains of the Araucanía Region, southern Chile. Lycalopex sp. was the species with most records, 8 times (in all, 25 records), whereas L. culpaeus was the species with least records (1 time). Lycalopex sp. could be either L. culpaeus, L. griseus or L. darwini, the three expected fox species to be detected for the study area. 
Table 2 Presence and absences of 6 species of carnivorous mammals in 7 fragments in the Coastal Mountains of the Araucanía Region, southern Chile. $\mathrm{N}=25$ records. Lycalopex sp. was recorded $\mathrm{n}=8$ times in the scent-stations; L. culpaeus $\mathrm{n}=1$ time; L. griseus $\mathrm{n}=$ 4 times; Conepatus chinga $\mathrm{n}=4$ times; Leopardus guigna $\mathrm{n}=2$ times; and Puma concolor $\mathrm{n}=6$ times

\begin{tabular}{|c|c|c|c|c|c|c|c|}
\hline Fragments/Species & $\begin{array}{c}\text { Lycalopex } \\
\text { sp. }\end{array}$ & $\begin{array}{r}\text { Lycalopex } \\
\text { paeus }\end{array}$ & cul- & $\begin{array}{r}\text { Lycalopex } \\
\text { griseus } \\
\end{array}$ & $\begin{array}{r}\text { Conepatus } \\
\text { chinga } \\
\end{array}$ & $\begin{array}{c}\text { Leopardus gui- } \\
\text { gna }\end{array}$ & $\begin{array}{c}\text { Puma con- } \\
\text { color }\end{array}$ \\
\hline Nueva Estruria & 0 & 1 & & 1 & 1 & 1 & 1 \\
\hline El Socorro & 1 & 0 & & 0 & 1 & 0 & 1 \\
\hline Boroa Norte 3 & 1 & 0 & & 0 & 1 & 0 & 1 \\
\hline Boroa Norte 1 & 1 & 0 & & 0 & 1 & 0 & 0 \\
\hline Licancullín & 1 & 0 & & 0 & 0 & 1 & 0 \\
\hline Afquintúe & 0 & 0 & & 1 & 0 & 0 & 0 \\
\hline Boroa Norte 2 & 1 & 0 & & 0 & 0 & 0 & 0 \\
\hline
\end{tabular}

Considering only the composition of species, it was found that the occupation percentage of the original matrix by 6 species of carnivorous mammals in 7 fragments of the Araucanía Region was $40.4 \%$ and therefore, the unoccupied percentage of the matrix was $59.6 \%$. According to the suggestion by Méndez (2004), it is important to consider the absence of species, since they suggest a low quality of habitat.

The temperature of the archipelago of fragments was $\mathrm{T}=28.21^{\circ}$ with the NTC program (Fig. 2). This suggests that the composition of carnivorous mammal species in the study area has not a pattern of nested subsets, indicating that they are not prone to local extinctions. However, according to the extinction curve of species (Figure 2), it is suggested to pay special attention to species 3 (Puma concolor) and 5 (Leopardus guigna), which present higher idiosyncratic temperatures at the matrix with maximum packaging.

Using the Monte Carlo technique, with the same program, the probability of statistical distribution of the nesting patterns in the archipelago of fragments by carnivorous mammals was calculated. After 500 iterations, the average temperature provided by the program was $\mathrm{T}=32.73^{\circ} \pm 12.58^{\circ}$, corroborating that the composition of carnivorous mammal species lacks a pattern of nested subsets.

The nesting temperature provided by the BINMATNEST software was 16.58450 degree Celsius and their variances (mean \pm var.) were $29.08886 \pm 75.66578 ;(p=0.1000)$ for model $1 ; 23.76208 \pm 91.32798(\mathrm{p}=0.26000)$ for model 2 and $26.49491 \pm 69.07679(\mathrm{p}=0.14000)$ for model 3. Therefore, in this study the model with "greater robustness" (i.e., least variance) was model 3 by Rodríguez-Gironés \& Santamaría (2006), followed by models 1 by Atmar \& Patterson (1995) and 2 by Fischer \& Lindenmayer (2002).

The determination coefficients obtained from the four types of simple regression analyses: linear, potential, logarithmic and exponential were $0.13,0.23,0.22$ and 0.16 , respectively, showing also a low correlation for all models with respect to the number of species (6) and area of the fragments (7), suggesting that the effects of fragmentation in the evaluated groups are not given at the level of species richness. 
Percentage of occupation $40.4 \%$ ( 6 species)

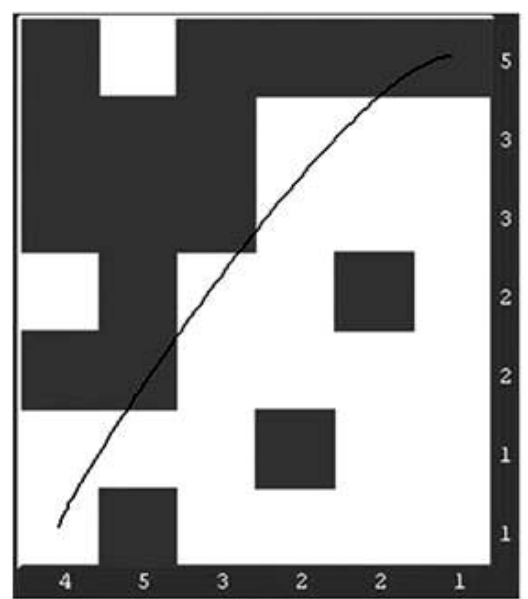

(a)

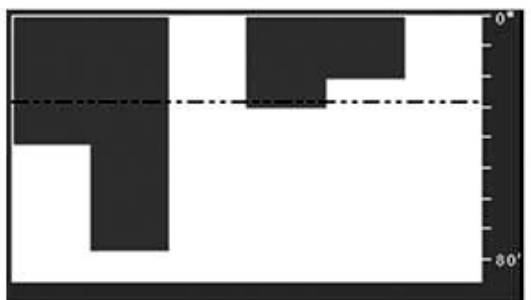

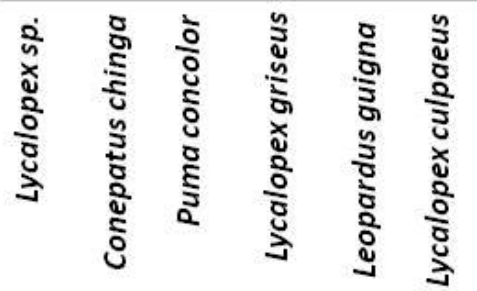

System temperature $28.21^{\circ}$ ( 7 fragments)

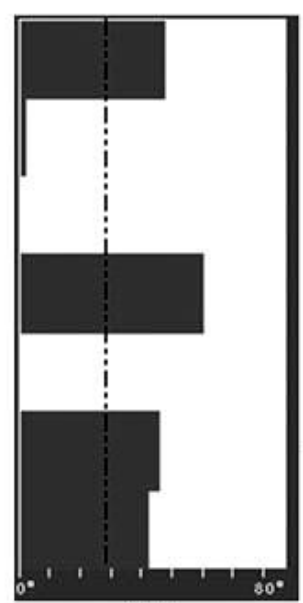

Nueva Estruria

El Socorro

Boroa Norte 3

Boroa Norte 1

Licancullín

Afquintúe

Boroa Norte 2

(c)

Figure 2 Matrix of maximum nesting for a carnivorous mammal assemblage in a landscape of fragmented forest in the Araucanía Region, southern Chile. The figure includes: (a) extinction curve, (b) idiosyncratic temperatures for the forest fragments studied, and (c) species of carnivorous mammals that inhabit them.

\section{Discussion}

The analysis carried out indicates that there is no nesting pattern at the level of species composition at the carnivorous mammal assemblage in the southern area of the Coastal Mountains of the Araucanía Region, southern Chile. This pattern could be due to the habitat use characteristics of the different carnivores studied here. Such is the case of Conepatus chinga, considered as rare (2-3 ind./ha), that inhabits different environments throughout its distributional range, from bushes, savanna, forest, mountains, high plateau, to parks and steppes (Donadio et al., 2001; Quintana et al., 2009). L. guigna, considered as scarce (4-5 ind/ha), is a forest specialist (Correa \& Roa, 2005), whereas the puma ( $P$. concolor), considered as occasional (0-1 ind./ha), "prefers" more open habitats or exotic plantations (Pinus radiate) of open canopy for its feeding (Muñoz-Pedreros et al., 1995; Lira-Torres \& Naranjo, 2003; Charre-Medellín et al., 2014). For the other hand, Lycalopex culpaeus and L. griseus, considered as rare and scarce, respectively, use forest habitats occasionally, since they prefer open habitats or bushes, with abundance in the environmental availability of small mammals (Murúa, 1995; Quintana et al., 2009; Zúñiga et al., 2009).

In this study, Licalopex sp., was recorded in almost all sampling sites (with the exception of Afquintúe of 6.8 ha and Nueva Etruria of 146.5 ha), whereas the other species of carnivores were recorded only in some sites. C. chinga was recorded in four sites, the two with the largest area (El Socorro with 2,309.1 ha and Nueva Etruria) and in two fragments with smaller areas (Afquintúe with 6.8 ha and Boroa Norte 3 with 3.1 ha). For the other 
hand, P. concolor was registered in two largest fragments (El Socorro and Nueva Etruria) and only in two small fragments (Licancullín with 46.8 ha) and Nueva Etruria.

It should be noted that although the presence of these highly mobile species has been attributed to these fragments, it can be recognized that probably these fragments only correspond to corridor or passage stepping-stones within their home range. The large home ranges presented by these species $\left(24-107 \mathrm{~km}^{2}\right.$ in Chilean Patagonia, Franklin et al., 1999) make their presence, rather than the presence and area of the fragments, attributable to the area in general.

Although, neither species richness not composition was affected by forest fragmentation, the results obtained in this study indicate the usefulness of the available analysis tools to establish a reference system to monitor future temporal and spatial changes in the pattern of nested subsets of the carnivorous mammal assemblage in the forest fragments of the Coastal Mountains of the Araucanía Region. In raptors birds have been established that in disturbed areas such as agroecosystems their composition is nested, as compared with a natural protected area (Rau et al., 2020). At present, the assemblage of carnivore mammals is not nested and prone to extinction but deforestation and fragmentation in Chilean temperate forests are very rapid (Echeverría et al., 2006). Thus, the monitoring of their rich endemic diversity of carnivore mammals could be mandatory.

\section{Acknowledgments}

Authors wish to thank the Dirección de Investigación de la Universidad de Los Lagos for support for this study. As well to Soraya Sade for her assistance with the editing of the text. Finally, RS wish to thank the Magister en Ciencias mención Producción, Conservación y Manejo de Recursos Naturales, Universidad de Lagos, Chile.

\section{References}

Acosta, G. \& J. Simonetti (1999). Guía de huellas de once especies de mamíferos del bosque templado chileno. Boletín del Museo Nacional de Historia Natural (Chile) 48: 19-27.

Acosta, G. (2001). Efecto de la fragmentación del bosque nativo en la conservación de Oncifelis guigna y Pseudalopex culpaeus en Chile central. Disponible en http://repositorio.uchile.cl/handle/2250/106679.

Atmar, W. \& B. D. Patterson (1995). The nestedness temperature calculator: a visual basic program, including 294 presence-absence matrices. AICS Research, Inc., University Park, NM and the Field Museum, Chicago, IL.

Charre-Medellín, J.F., T.C. Monterrubio-Rico, D. Guido-Lemus \& E. Mendoza (2015). Patrones de distribución de felinos silvestres (Carnivora: Felidae) en el trópico seco del Centro-Occidente de México. Revista de Biología Tropical 63:783-797.

Correa, P. \& A. Roa (2005). Relaciones tróficas entre Oncifelis guigna, Lycalopex culpaeus, Lycalopex griseus y Tyto alba en un ambiente fragmentado de la zona central de Chile. Mastozoología Neotropical, 12(1), 57-60.

Crooks, K. (2002). Relative sensitivities of mammalian carnivores to habitat fragmentation. Conservation Biology, 16(2): 488-502.

Donadio, E., S. di Martino, M. Aubone \& A.J. Novaro (2001). Activity patterns, home-range, and habitat selection of the common hog-nosed skunk, Conepatus chinga (Mammmalia, Mustelidae), in north-western Patagonia. Mammalia, 65: 49-54.

Echeverría, C. (2012). How landscapes change: integration of spatial patterns and human processes in temperate landscapes of southern Chile. Applied Geography, 32, 822-831.

Echeverría, C., D. Coomes, J. Salas, J.M. Rey-Benayas, A. Lara \& A. Newton (2006). Rapid deforestation and fragmentation of Chilean temperate forests. Biological Conservation, 130 (4):481-494

Fisher, J. \& D. B. Lindermayer (2002). Treating the nestedness temperature calculator as a "black box" can lead to false conclusions. Oikos, 99: 193-199.

Franklin, W.L., W.E. Johnson, R.J. Sarno \& J.A. Iriarte (1999). Ecology of the Patagonia puma Felis concolor patagonica in southern Chile. Biological Conservation, 90: 33-40.

Gajardo, R. (1993). La vegetación natural de Chile. Clasificación y distribución geográfica. Editorial Universitaria, Santiago. 165 pp.

García, D. (2011). Efectos biológicos de la fragmentación de hábitat: nuevas aproximaciones para resolver un viejo problema. Ecosistemas, 20(2-3): 1-10.

Hauenstein, E. (2002). Clasificación y caracterización de la flora y vegetación de los humedales de la costa de Toltén, IX Región, Chile. Gayana Botánica, 59: 91-104.

Lindenmayer, D. \& J. Fischer (2006). Habitat fragmentation and landscape change: an ecological and conservation synthesis. University of Chicago Press, Chicago. 328 pp.

Lira-Torres, I. \& E. Naranjo (2003). Abundancia, preferencia de hábitat e impacto del ecoturismo sobre el puma y dos de sus presas en la reserva de la biósfera El Triunfo, Chiapas, México. Revista Mexicana de Mastozoología, 7: 21-40. 
Méndez, M. (2004). La composición de especies de aves en islas y paisajes fragmentados: un análogo ecológico de las muñecas rusas. El Drake, 5: 199-212.

Muñoz-Pedreros, A., J.R. Rau, M. Valdebenito, V. Quintana \& D.R. Martínez (1995). Densidad relativa de pumas (Felis concolor) en un ecosistema forestal del sur de Chile. Revista Chilena de Historia Natural. 68:501-507.

Murúa, R. (1995). Comunidades de mamíferos del bosque templado de Chile. En: Armesto, J.J, C. Villagrán \& M.K. Arroyo (eds.). Ecología de los bosques nativos de Chile. Pp. 113-133. Editorial Universitaria. Santiago. 477pp.

Noss, R.F., H.B. Quigley, M.G. Hornocker, T. Merrill \& P.C. Paquet (1996) Conservation biology and carnivore conservation in the Rocky Mountains. Conservation Biology, 10: 949-963.

Otavo, S. \& C. Echeverría (2017). Fragmentación progresiva y pérdida de hábitat de bosques naturales en uno de los hotspot mundiales de biodiversidad. Revista Mexicana de Biodiversidad, 88:924-935.

Quintana, V., J. Yánez, M. Valdebenito \& A. Iriarte (2009). Orden Carnivora. En: Muñoz-Pedreros, A. \& J. Yáñez (eds) Mamíferos de Chile: 193-230. CEA Ediciones, Valdivia. $571 \mathrm{pp}$.

Rau, J.R. (2020). Subconjuntos anidados de rapaces en el sur de Chile: comparación entre un Área Natural Protegida y otra de uso pecuario. Áreas Naturales Protegidas Scripta 6: 1-9.

Rau, J.R., A. Gantz, S. Sade \& J.I. Orellana (2016). Patrones de subconjuntos anidados de aves rapaces en fragmentos de bosque del sur de Chile. Boletín Chileno de Ornitología, 21(1-2): 76-82.

Rodríguez-Gironés, M.A. \& L. Santamaría. (2006). A new algorithm to calculate the nestedness temperature of presence-absence matrices. Journal of Biogeography 33: 924-935.

Santos, T. \& J. L. Tellería (2006). Pérdida y fragmentación del hábitat: efecto sobre la conservación de las especies. Ecosistemas, 2: 3 12.

Suárez-Tangil, B. \& A. Rodríguez (2021) Estimates of species richness and composition depends on detection method in assemblages of terrestrial mammals. Animals 11, 186. https://doi.org/10.3390/ani 11010186

Swihart, R.K., T.M. Gehring, M.B. Kolozsvary \& T.E. Nupp (2003) Responses of "resistant" vertebrates to habitat loss and fragmentation: the importance of niche breadth and range boundaries. Diversity and Distributions, 9: 1-18.

Ulrich, W. \& N. J. Gotelli (2007a). Null model analysis of species nestedness patterns. Ecology, 88: 1824-1831.

Ulrich, W. \& N. J. Gotelli (2007b). Disentangling community patterns of nestedness and species co-ocurrence. Oikos, 116: $2053-2061$.

Ulrich, W, M. Almeida-Neto \& N. J. Gotelli (2009). A consumer's guide to nestedness analysis. Oikos, 118: 3-17.

Wright, D. H., B.D. Patterson, G.M. Mikkelson, A. Cutler \& W. Atmar (1998). A comparative analysis of nested subset patterns of species composition. Oecologia, 113: 1-20.

Zúñiga, A., A. Muñoz-Pedreros \& A. Fierro (2009) Uso de hábitat de cuatro carnívoros terrestres en el sur de Chile. Gayana, 73: 200210 . 